\title{
Assessment of Yield Attributes and Industrial Quality Parameters of Oat Cultivars (Avena sativa L.) Using Multivariate Techniques (PCA, PLS-DA and OLS-R)
}

\author{
Virgílio Gavicho Uarrota ${ }^{1}$, Clovis Arruda Souza ${ }^{1^{*}}$ \\ Julhana Cristina Sponchiado ${ }^{1}$ and Cileide Maria Medeiros Coelho ${ }^{2}$ \\ ${ }^{1}$ Laboratory of Crop Plants, Agroveterinary Science Center, Department of Agronomy, Santa Catarina \\ State University, Luiz de Camões Avenue 2090, Zip Code 88520-000, Lages, SC, Brazil. \\ ${ }^{2}$ Laboratory of Seed Analysis, Agroveterinary Science Center, Department of Agronomy, Santa \\ Catarina State University, Luiz de Camões Avenue 2090, Zip Code 88520-000, Lages, SC, Brazil.
}

Authors' contributions

This work was carried out in collaboration between all authors. Author VGU drafted and performed the data mining in $R$ software. All other authors contributed equally in data collection, analysis and discussion. All authors read and approved the final manuscript.

Article Information

DOI: $10.9734 / J E A I / 2017 / 35506$

Editor(s):

(1) Simon Wallace, Department of Biology, University of lowa, lowa City, USA. (2) Funda Eryilmaz Acikgoz, Department of Plant and Animal Production, Vocational College of Technical Sciences, Namik Kemal University, Turkey. Reviewers:

(1) Essam Fathi Mohamed El-Hashash, Al-Azhar University, Egypt. (2) Jayath P. Kirthisinghe, University of Peradeniya, Sri Lanka. Complete Peer review History: http://www.sciencedomain.org/review-history/20872

Original Research Article

Received $17^{\text {th }}$ July 2017 Accepted $19^{\text {th }}$ August 2017 Published $8^{\text {th }}$ September 2017

\begin{abstract}
Triazoles and strobilurins group of fungicides have been reported to have dual properties (growth regulator and fungicide) and have been used to prevent the plant lodging. In this study four subsequent field experiments with oat cultivars with and without fungicide application were conducted from 2012 to 2015 aiming to find if fungicide application can improve some yield attributes and quality parameters of oats and find yield attributes that most affect the quality parameters of oats. Multivariate techniques were applied in other to find the most important variables that contribute to sample classification. Fungicide application has a role in reducing the plant stature of oat cultivars with consequent decreasing in lodging index of oat cultivars. Fungicide
\end{abstract}

*Corresponding author: E-mail: clovis.souza@udesc.br;

E-mail: uaceleste@yahoo.com.br; 
application reduces the plant stature and lodging index, contributing to best quality parameters of oats. Multivariate techniques (PCA, PLS-DA, OLS-R) were capable in finding the important variables that affect yield attributes and quality parameters and can be applied in a broad range of agricultural systems for predicting important aspects that affect plant growth and development.

Keywords: Oats; fungicide application; de-hulling index; yield attributes; quality parameters; multivariate techniques; plant stature.

\section{ABBREVIATIONS}

$$
\begin{array}{ll}
\text { PCA } & \text { Principal component analysis; } \\
\text { PLS-DA : } & \text { Partial least squares discriminant } \\
& \text { analysis; } \\
\text { OLS-R : } & \text { Ordinary least squares regression, } \\
\text { LV : } & \text { Latent variables, } \\
\text { VIP : } & \text { Variable importance projections, } \\
\text { AIC : } & \text { Akaike information criterion. }
\end{array}
$$

\section{INTRODUCTION}

Oats (Avena sativa L.) are an important spring cereals [1,2]. They are fast growing and produces significant amount of fresh fodder within short period (60-70 days) with adequate nutritional value [3]. Independent of the end use, quality requirements are of great importance. The identification of agronomic traits that meet the demand of farmers, industry quality and final consumers, and their incorporation into elite oat germplasm are crucial to the development of successful new oat cultivars. Some of the most important traits selected by the Brazilian Oat Breeding Program include wide adaptation, high grain yield and grain quality, short plant cycle, reduced plant height, lodging resistance, frost tolerance, aluminum tolerance, and genetic resistance to the main diseases, such as crown and stem rust, leaf spot, fusarium, and barley yellow dwarf virus [4]. In this research the use of a mixture of fungicides claimed to have growth retardant effect is explored aiming a better assessment of yield attributes and quality parameters of oats.

Triazole fungicides are one of the top ten classes of current-use pesticides and have higher consumption as compared to other fungicides available worldwide [5]. They inhibit the biosynthesis of fungal ergosterol [6] and provide a broad spectrum of activities [7] such as plant growth regulators [7]. The mechanism of regulatory effect appears to be that they shift the phytohormone balance in plant tissues and inhibit the biosynthesis of gibberellic acid, which leads to a transient raise in abscisic acid content in plants [7] Tebuconazole (TEB) is one of a common triazole fungicide that has been extensively used in grains, vegetables and fruits for the control of plant pathogenic fungi [7-9]. Additionally, the strobilurins are a new class of fungicidal compounds and among them is the recently introduced trifloxystrobin $[10,11]$ that is highly effective against several plant pathogens [12-14]. Mode of action of the strobilurins towards pathogenic fungi was found to block the mitochondrial respiratory electron transfer chain between cytochrome $\mathrm{b}$ and cytochrome $\mathrm{c} 1$ at the ubiquinol oxidizing site (Qo) of the complex III, ultimately leading to losses of ATP synthesis and inhibition of cellular respiration, which is also deemed to contribute its broad-spectrum antifungal activity [15]. Triazoles and strobilurins have been reported to have secondary properties (e.g., growth regulator) and have been used to prevent the plant lodging [16]. From a biochemical point of view, the properties of some triazoles are due to their dual effect on plants: inhibition of the biosynthesis of gibberellins in the plant (retardant properties), and inhibition of the biosynthesis of sterols (fungicide properties [16]). As growth regulators their act not only as chemicals that modulate plant growth but they also act as signal molecules under various biotic and abiotic stresses [17]. As growth retardants, triazoles and strobilurins are applied in agronomic and horticultural crops to reduce unwanted longitudinal shoot growth without lowering plant productivity. Most growth retardants act by inhibiting gibberellin (GA) biosynthesis [18]. Currently, it is a common practice in crop protection to apply multiple pesticide mixtures instead of individual pesticides. This form of pesticide application likely results in the combined effect [19]. In this research the retardant effect of the fungicides is explored in oat cultivars aiming to ameliorate the lodging index and thereby improve yield and quality requirements of oats. Multivariate techniques were used to assess yield attributes and quality requirements of oat cultivars subjected to two different treatments (without and with fungicide application). 


\section{MATERIALS AND METHODS}

\subsection{On Farm Experiments}

Subsequent on farm experiments were conducted in Lages (Santa Catarina State, Southern Brazil, on an experimental research field of the Santa Catarina State University) from 2012 to 2015, using split plot design with and without aerial fungicide application of a mixture of tebuconazole (triazole group) $(150 \mathrm{~g} / \mathrm{Ha})$ and trifloxystrobin (strobilurin group) (56 g/Ha). All other agronomic practices (such as soil fertilization, weed and disease control) were performed following the Brazilian commission for oat research recommendations [20]. Each plot (useful area) consisted of 5 central lines of $5 \mathrm{~m}$ of length spaced at $0.2 \mathrm{~m}$. 3 repetitions (blocks) were used. A mechanized harvest of the oat grains was done for subsequent laboratory analyses. A total of 21 oat cultivars were evaluated (see supplementary Table 1) during four subsequent years (from 2012 to 2015).

\subsection{Yield Components Analysis}

Yield attributes such as plant stature $(\mathrm{cm})$, grain yield $(\mathrm{Kg} / \mathrm{Ha})$ and weight of 1000 grains and sieve yield $(>2 \mathrm{~mm})$ were evaluated at each experiment (2012-2015). Other yield attributes were evaluated previously (unpublished data from 2007 to 2010).

\subsubsection{Plant stature $(\mathrm{cm})$}

Evaluated on plants at growth stage GS91 (preharvest maturity) by measuring 10 plants in a random points in each plot by the use of a ruler. The measurements were done from the soil surface until the apical spikelet located on the top of the panicle and values expressed as mean of 10 plants according to equation 1.

$$
\left.P S(c m)=\frac{\sum_{n=1}^{n=10} p s}{N}\right]
$$

Where PS is the plant stature in $\mathrm{cm}$; ps-individual plant stature, $\mathrm{N}$ is the total number of plants evaluated in each plot (10).

\section{$\underline{2.2 .2}$ Sieve yield $(>2 \mathrm{~mm})$}

Refers to the percentage of grains with transverse diameter greater than $2 \mathrm{~mm}$, This was evaluated after harvest, by weighing a sample of $250 \mathrm{~g}$ and then submitted the sieve with regular stirring during a minute; in a sieve of $40 \mathrm{~cm} \times 30$ $\mathrm{cm}$ dimensions, rectangular, containing holes (sieve) of $2 \mathrm{~mm} \times 20 \mathrm{~mm}$. This process was done twice. The result was expressed by the fraction between the grain weight retained on the sieve and the initial weight $(250 \mathrm{~g})$ as represented in the equation 2 .

$$
\left[S y(\%)=\frac{R G W}{I G W} * 100\right]
$$

Where Sy is the sieve yield ( $>2 \mathrm{~mm})$; RGW is the retained grain weight in a sieve and IGW is the initial grain weight ( $250 \mathrm{~g}$ for this experiment).

\section{$\underline{2.2 .3}$ Yield $(\mathrm{Kg} / \mathrm{Ha})$}

The grain yield was measured from each experimental plot (4 central linear meters of each plot, spaced at $0.2 \mathrm{~m}$, in a useful area of $2.4 \mathrm{~m}^{2}$ ). The yield was then converted to hectare after weight correction using a standard moisture content of $13 \%$ according to equation 3 .

$$
\left[\text { yield }=\frac{\left(w w *\left(\frac{100-r m}{100-13}\right)\right)}{2.4 * 10000}\right]
$$

Where: ww - wet weight $(\mathrm{Kg})$ and $\mathrm{rm}$ is the real weight moisture (\%).

\subsubsection{Weight of 1000 grains $(\mathrm{Wg})$}

A sample of a thousand grains', obtained from each experimental plot were electronically counted (Sanick ESC 2011) and weighted using a precision balance and expressed in grams (g).

\subsection{Quality Parameters}

Quality requirement parameters of the grains independent of end use such as lodging index, weight of hectoliter $(\mathrm{Kg} / 100 \mathrm{~L})$, and the de-hulling index were evaluated.

\subsubsection{The lodging index}

Estimated visually and expressed as a percentage, taking into account the angle formed in the vertical position of the plant stem in relation to the ground. $5 \mathrm{~m}^{2}$ of area was used. The methodology of Moes and Stobbe [21] was 
used and the lodging index expressed according to the equation 4 .

$$
[\operatorname{Li}(\%)=I * A * 2]
$$

Where (Li) is the lodging index; (I) -the degree of inclination of plants, ranging from 0 to 5 , where 0 represents absence of inclination (all plants in a vertical position), while 5 indicates that all plants are completely bedridden (horizontally); (A) represents the area with lodged plants, ranging from 0 to 10 , where 0 corresponds to the absence of lodged plants in the plot, and 10 all plants lodged.

\subsubsection{Weight of hectoliter $(\mathrm{Kg} / 100 \mathrm{~L})$}

The weight of hectoliter was measured according to the Brazilian official wheat grain quality roles (Brazil, Ministry of Agriculture, Livestock and supply, Normative role 38 , from November 30 of 2010), using an hectoliter weight analyzer (DalleMolle, model T40EL, $0.25 \mathrm{~L}$ of capacity). Briefly, grain samples from each experimental plot were placed in the analyzer for volume determination and then weighed. The hectoliter weight (HW) was then expressed according to equation 5 .

$$
\left[H W=W v^{*} 0.4\right]
$$

HW is the hectoliter weight; Wv represent the weight of the sample after volume determination in analyzer and 0.4 is a calibration coefficient of the equipment.

\subsubsection{De-hulling index (\%)}

A sample of 1000 grains was weighed, de-hulled manually and then weighed again. The de-hulling index expressed as in equation 6.

$$
\left[D H I(\%)=\frac{W 1000 g}{w d h} * 100\right]
$$

$\mathrm{DHI}$ is the de-hulling index, W1000 $\mathrm{g}$ the weight of 1000 grains before de-hulling and wdh is the weight of the sample after de-hulling.

\subsection{Data mining and Statistics}

Data from each year were summarized, subjected to normality test, homogeneity of variance test, analysis of variance using a split plot design and where differences were found, Tukey HSD $(P<0.05)$ was used to test if the differences are statistically significant. Nonsupervised multivariate analysis (principal component analysis-PCA was also applied aiming to observe similarities between the tested cultivars and find variables main related to the similarities. Ordinary least squares regression models (OLS-R) were also applied aiming to find the importance of each variable and those mostly affected the cultivars and quality parameters. A second approach (supervised techniques) namely partial least squares discriminant analysis (PLS-DA) aiming to better classify the samples and find the main variables related to quality parameters were used for dimensionality reduction and find the between and within class variance of the dataset. All statistical analyses were done in $R$ software [22] using functions, $R$ packages and scripts produced by our research group. A report is also available as supplementary data for data reproducibility.

\section{RESULTS AND DISCUSSION}

Results of the analysis of variance (ANOVA) and multiple comparison tests (Tukey test, $5 \%$ of probability) of the four field experiments (2012 to 2015) showed to exist differences between cultivars and the effect of fungicide application regarding the de-hulling index $(\mathrm{DHI})$, hectoliter weight $(\mathrm{HW})$, loading index ( $\mathrm{Li})$, weight of 1000 grains $(\mathrm{Wg})$, plant stature (PS), sieve yield (Sy) and grain yield (Yield- see supplementary report for ANOVA and multiple comparison tests). Statiscally significant higher value of $\mathrm{DHI}$ was found for cultivar URS-BRAVA and the lower value observed for URS-FAPA-SLAVA (Tukey test, $p<0.05)$. Cultivars URS-GURIA and URSTARIMBA presented higher loading index and lower indices were observed for IPR-AFRODITE, URS-TAURA and UPFA-OURO. Regarding the plant stature, cultivars URS21 and URS-GURIA presented plants with superior stature and URSTAURA with lower stature. The sieve yield was higher in UPFPS-FARROUPILHA, URSTORENA, URS-TAURA, URS-CORONA and URS-GUAPA and lower in the cultivar URSFAPA-SLAVA. The weight of 1000 grains was found to be higher in the cultivars FAEM006 and UPFPS-FARROUPILHA and lower in cultivars URS-FAPA-SLAVA, BARBARASUL, BRISASUL and URS-ESTAMPA. Finally, the grain yield was higher in UPFA-OURO and IPR-AFRODITE and lower in URS-ESTAMPA and FAEM5CHIARASUL. Regarding the fungicide effect in all parameters evaluated, it was observed that fungicide application improved all parameters. 
Interestingly, the lodging index was higher without fungicide application (see supplementary report).

Previous studies $[3,23,24]$ have reported that cultivars have significant differences in plant height and variations are duo to genetic make-up and can also be affected by nitrogen. According to Brunava [25], higher yield was found in plants with lower plant height. This parameter can be affected by agronomic management practices such as seeding rates, chemical seed treatments and foliar fungicide. In a research of Mourtzins and co-workers [26], seeding rate and seed treatments did not show effect on oat yield, plant height and lodging index, but foliar fungicide application was considered mainly if disease is expected and improved the grain yield [26,27]. Higher values of the weight of 1000 grains were correlated with dough periods, good processing quality and are dependent of cultivar [25].

Follmann and co-workers [28] studying the genetic progress of oat cultivars with fungicide application reported an annual genetic progress in yield in $1 \%$ with fungicide and $0.08 \%$ without fungicide application. They reported that Fungicide application is feasible method. Fungicide application also improved the hectoliter weight. The hectoliter weight $(\mathrm{HW})$ is a measure of the bulk density of the grain and is indicator of grain quality and millability. To ensure effective milling, the HW should be above $50 \mathrm{Kg}^{-\mathrm{hl}^{-1}}$ for oats, as consequence,

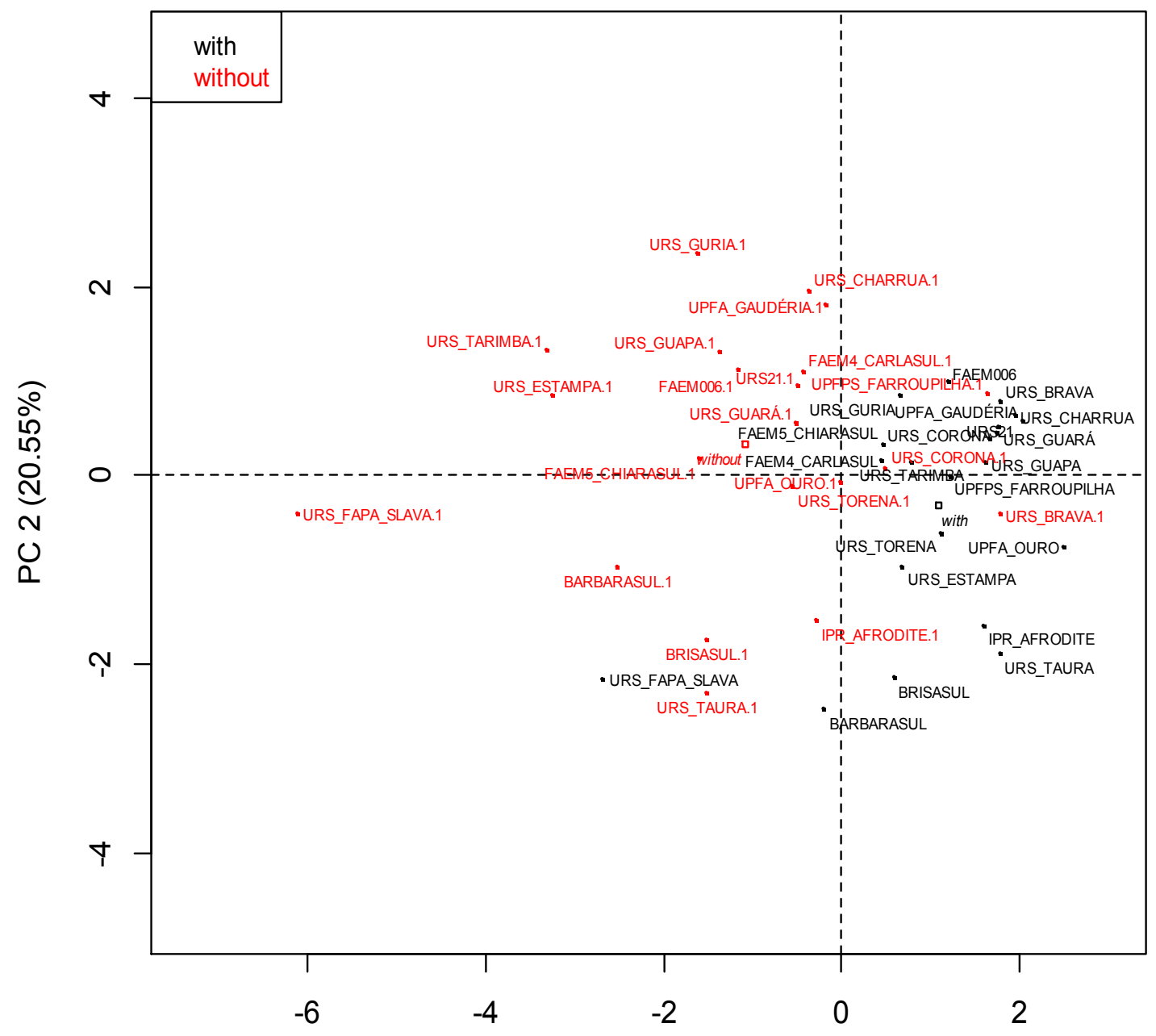

PC $1(45.50 \%)$ 
The Squared loadings

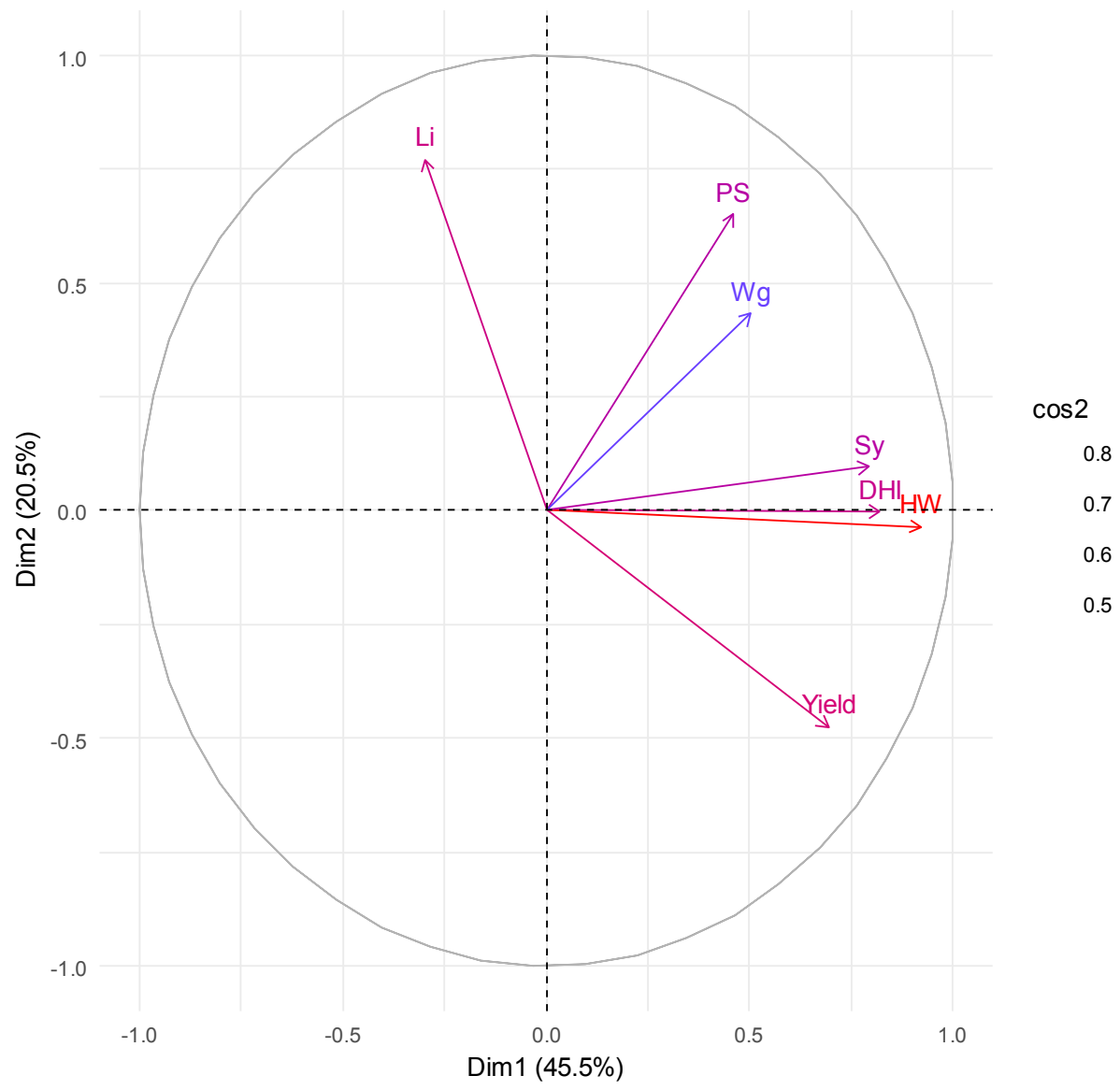

B

Fig. 1. (A) Score plots and (B) squared loadings of the principal component analysis (PCA) of oat cultivars studied

grains with high HW commands a higher price per ton, but the measured value is a combination of grain characteristics including friction, grain shape and polydispersity [28]. HW was claimed to be influenced by moisture during storage and nitrogen adubation [29,30]. Emvula [31] reported that HW can be affected plant stress, soil fertility, and environmental conditions, i.e., anything that impacts the movement of nutrients to the kernel during grain filling.

De-hulling index is another important characteristic in oat grains. High hull content of oats limits use as on farm-feed. The oat hull is mainly fibre, hemicellulose, cellulose and lignin. There are low levels of protein, fats, starch and water-soluble carbohydrates. As a result, digestibility of oat hull is low. For these reasons, high hull content of oat groat is a major determinant of decreasing nutritional quality, which is important if oat is used for feed. Reduction of the proportion of hulls in grains evidently results in marked increase in metabolized energy content when it's used in animal feed [32].

Lodging in small grains such as oat is a problem of considerable importance. Its effects on yield, HW, seed quality and other characteristics have been reported. The need for lodging resistant cultivars is becoming more urgent. Lodging was reported to be affected by environmental conditions attending the development of the plant as well as genetic make-up of the plant itself [33]. Lodging will always have a negative effect on yield. Yield losses in lodged crops come as a result of poor grain filling, head loss and bird damage [33]. Lodging alters the plant's growth and development, affecting flowering and interfering with photosynthesis and carbohydrate 
movement within the plant. It can interfere with plant's ability to extract nutrients and moisture from the soil, resulting in incomplete grain fill and smaller kernels. This can give yield losses of up to $40 \%$ depending on the severity and timing of the lodging [33]. In this sense of ideas, fungicide application can be an alternative to reduce lodging in oat plants.

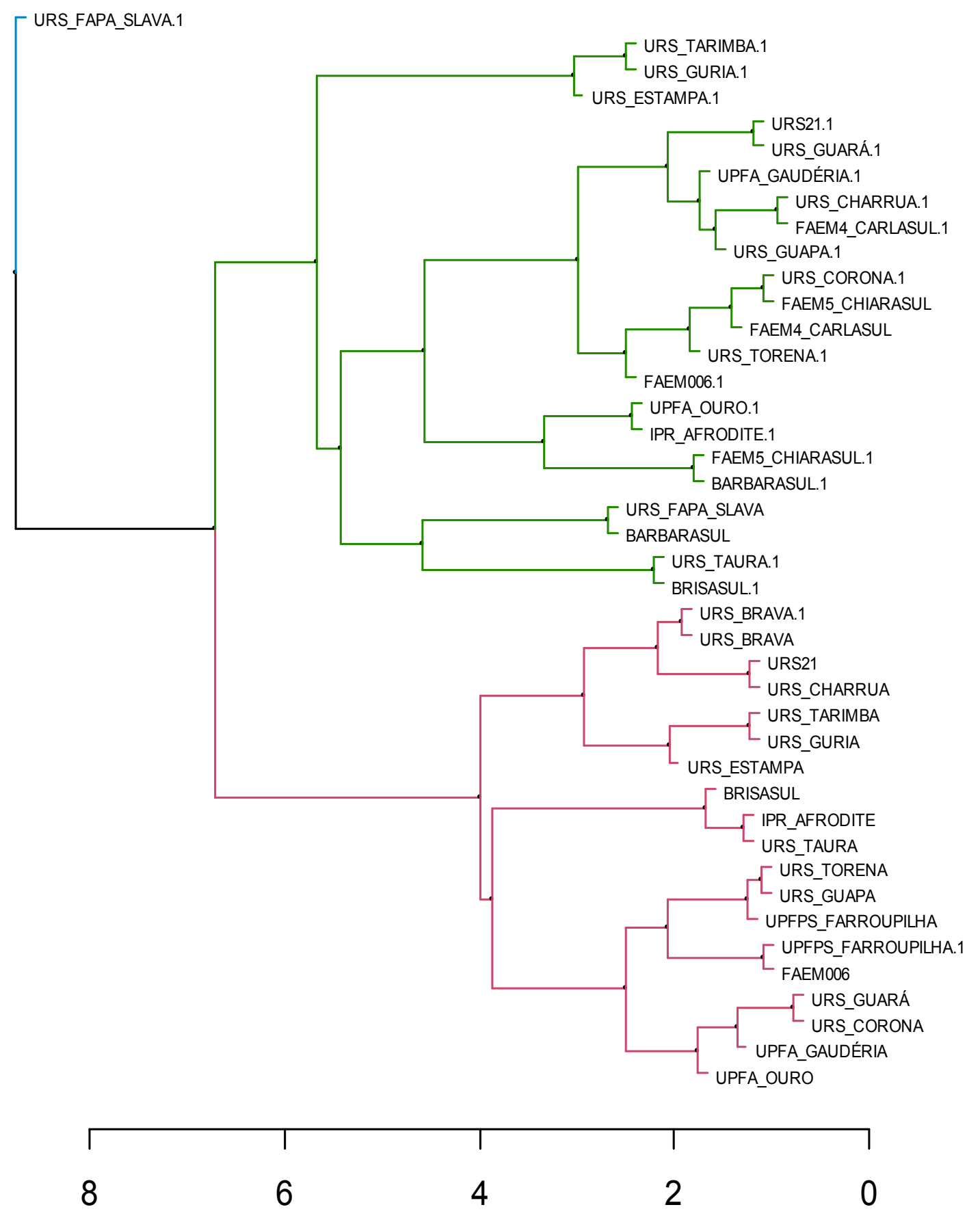

Fig. 2. Hierarchical cluster dendrogram of all cultivars studied showing sample similarities and dissimilarities. A cophenetic correlation of $92 \%$ was found 
Table 1. Pearson correlations of all variables studied

\begin{tabular}{|c|c|c|c|c|c|c|c|}
\hline \multirow{2}{*}{\multicolumn{8}{|c|}{ Application }} \\
\hline & & & & & & & \\
\hline $\mathrm{Li}$ & $-0.19^{* * * *}$ & & & & & & \\
\hline PS & $0.18^{* * * *}$ & $0.47^{* * * *}$ & & & & & \\
\hline Sy & $0.38^{* * * *}$ & $-0.16^{* * * *}$ & $0.16^{* * * *}$ & & & & \\
\hline $\mathrm{Wg}$ & $0.41^{* * * *}$ & $-0.33^{* * * *}$ & 0.06 & $0.29 * * * *$ & & & \\
\hline Yield & $0.47^{* * * *}$ & $-0.34^{* * * *}$ & $-0.18^{* * * *}$ & 0.09 & $0.26^{* * * *}$ & & \\
\hline Application & $0.30 * * * *$ & -0.06 & 0.06 & $0.14^{*}$ * & 0.07 & $0.40^{* * * *}$ & \\
\hline Cult & 0.00 & 0.08 & 0.02 & 0.00 & -0.07 & -0.07 & 0.00 \\
\hline
\end{tabular}

Aiming to better understand if there is an association of all variables studied, a Pearson correlation was performed (Table 1). Interestingly, fungicide application was positively correlated with all variables except for lodging index where a negative association was found, that prompt us to speculate that the application of fungicide reduce the lodging of oat plants. Lodging index was negatively associated with sieve yield, weight of 1000 grains and yield, important parameters in oat industry.

Looking to find the important variables in our dataset and dimensionality reduction, a second approach (non-supervised (principal component analysis -PCA, hierarchical cluster analysis $\mathrm{HCA}$ ) and supervised multivariate techniques (partial least squares discriminant analysis -PLSDA, ordinary least sqares regression -OLS-R)) was applied. When PCA was applied to the dataset (Fig. 1A) an interesting insight was observed. A good separation from cultivars where fungicide was applied and not applied was clearly observed (Fig. 1A) except for cultivars URS-TORENA, URS-BARAVA, URS-CORONA, IPR-AFRODITE who showed to be similar with those where fungicide was applied (Fig. 1A). A similar trend was also found for URS-FAPASLAVA (without fungicide application) who showed to be similar with BRISASUL and URSTAURA (with fungicide application). The total variance explained by PCA was $66.05 \%$, being 45.50 and $20.55 \%$ for component 1 (PC1) and 2 (PC2) respectively. The loading values are also presented in the Fig. 1B. The important variables that classified samples can be observed in squared loadings (Fig. 1B) and were the grain yield, de-hulling, hectoliter, sieve yield and plant stature. Plant stature and the lodging index highly affected cultivars without fungicide application. Fungicide application mostly affected the yield, de-hulling index, hectoliter weight and the sieve yield. Interestingly, our findings prompt us to state that taller plant stature observed without fungicide lead to high lodging index for the same plants. Sample clustering in PC1 were duo hectoliter weight, de-hulling index, sieve yield and grain yield (see supplementary report for contribution of the variables) and in PC2 duo to lodging index, plant stature and yield. In general manner, the variables hectoliter weight, yield, lodging index and de-hulling most contributed to the data variability. The scores of PCA indicated that 09 cultivars highly contributed to the variability (URS-FAPA-SLAVA, URSTARIMBA, URS-ESTAMPA, URS-GURIA, URSTAURA, BARBARASUL, UPFA-OURO, BRISASUL and IPR-AFRODITE). A hierarchical cluster dendrogram (HCA) is also presented in the Fig. 2. As it can be observed, a clear separation of the cultivars was found. 3 different groups can be observed in the HCA. URS-FAPASLAVA (without fungicide application) grouped alone. Samples where fungicide was applied grouped together except of a simple misclassification for UPSPF-FARROUPILHA and URS-BRAVA. HCA analysis reinforced the results previously observed in PCA analysis that lead us to state that the application of fungicide have a role in agronomic and quality parameters of oat cultivars evaluated.

The second approach applied in data screening and finding important variables was the use of regression models, at this time, an ordinary least square regression (OLS-R). The influence of all variables was measured. Firstly in the model 1 was tested the influence of the cultivars and in the model 2 was tested the effect fungicide application on quality parameters (hectoliter weight, de-huuling index and lodging index). Ordinary least squares (OLS) or linear least squares is a method for estimating the unknown parameters in a linear regression model, with the goal of minimizing the differences between the observed responses in some arbitrary dataset 
and the responses predicted by the linear approximation of the data The resulting estimator can be expressed by a simple formula, especially in the case of a single regressor on the righthand side. The results from OLS-R models are summarized in the Table 2 together with the akaike information criterion (AIC) and the variance explained by each model are presented. Looking for the second model (with better AIC), quality parameters were positively influenced by the plant stature. Without fungicide application, sieve yield, weight of 1000 grains and yield are affected.

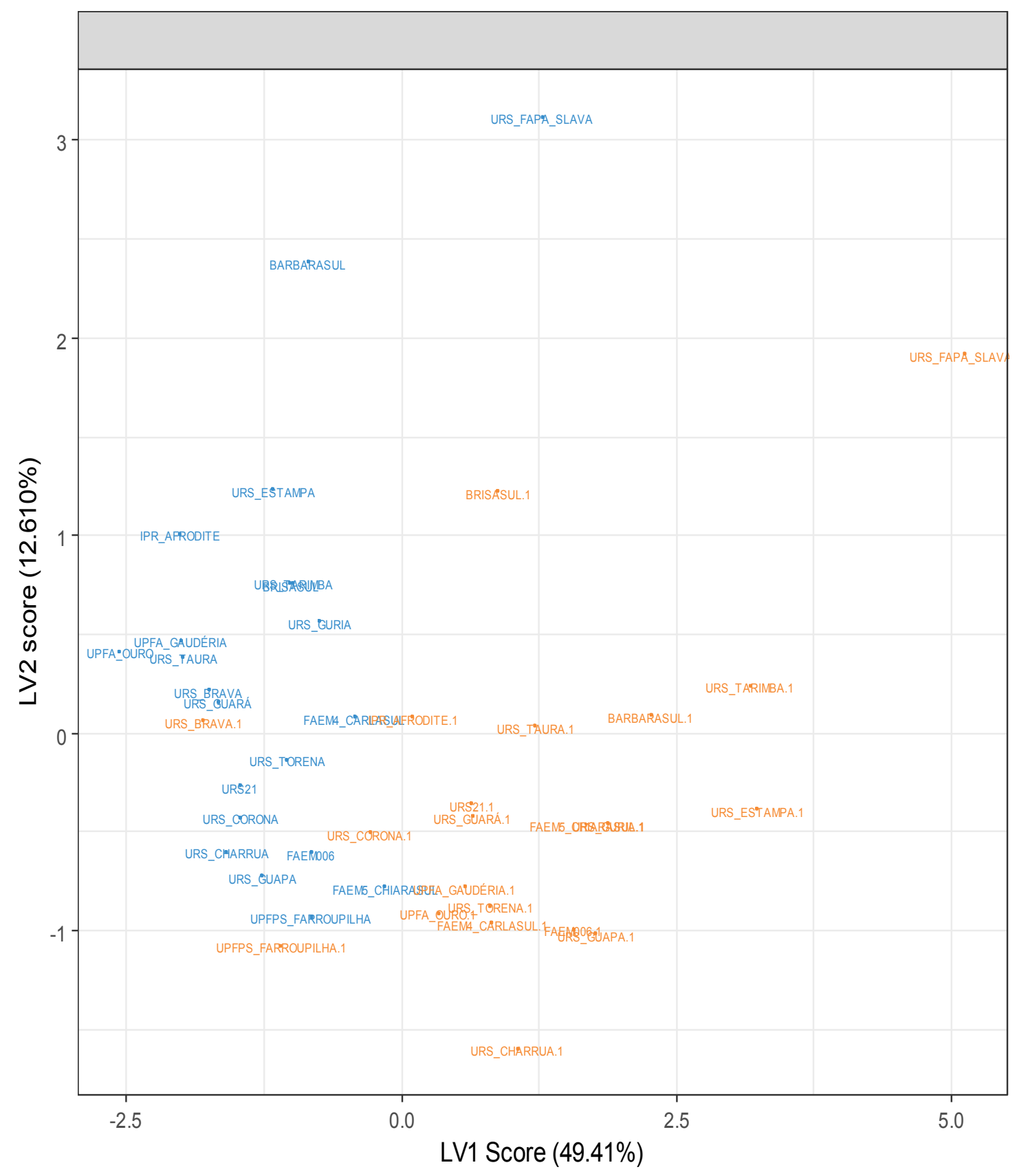

A 


\section{Circle of Correlations on $t_{1}, t_{2}$}

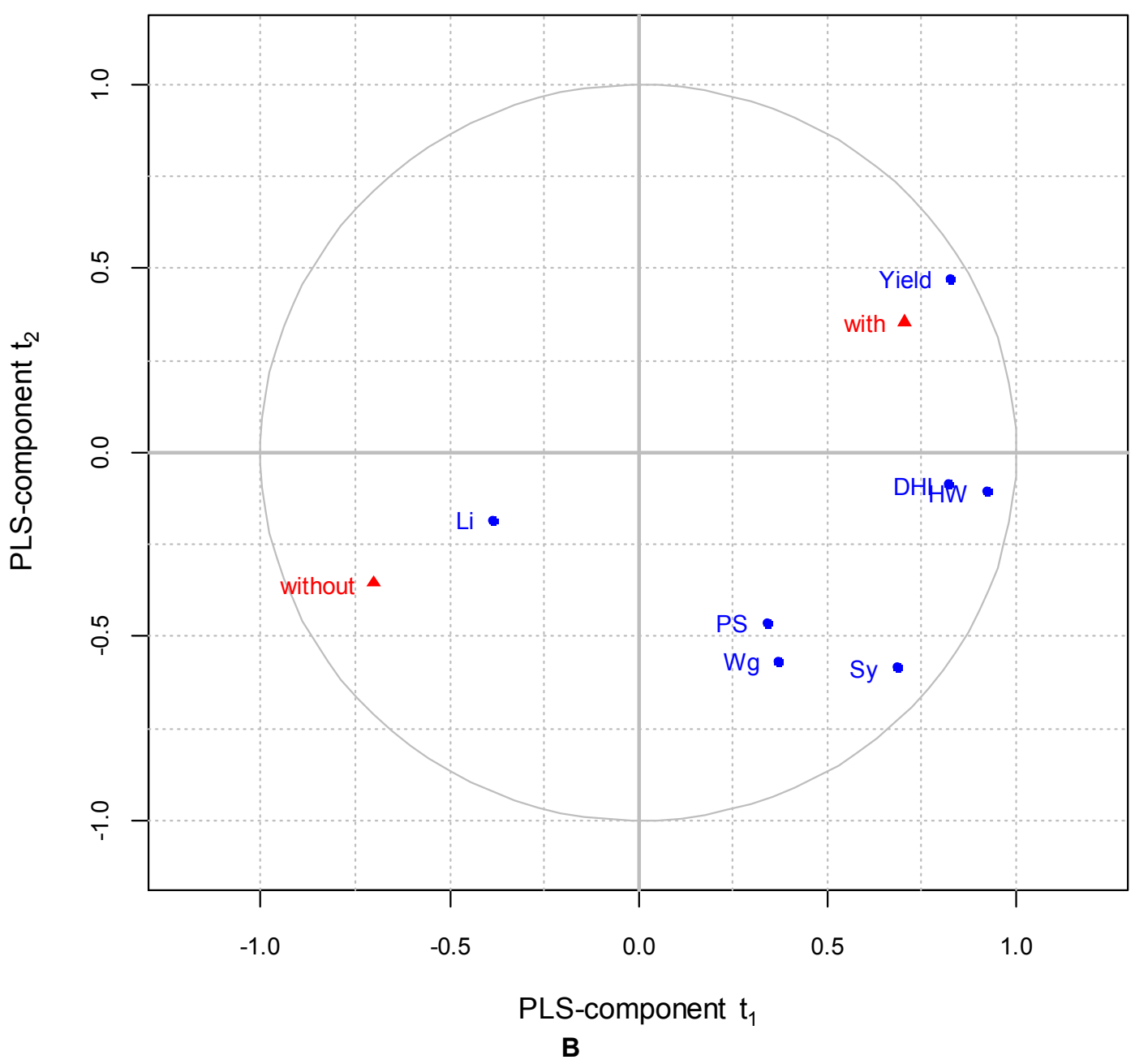

Fig. 3. (A) Score plot of partial least squares discriminant analysis oat cultivars dataset and (B) the circle of correlations showing the variables most correlated with and without fungicide application

Finally, the dataset was also subjected to partial least squares discriminant analysis (PLS-DA). Partial least square (PLS) is a versatile algorithm which can be used to predict either continuous or discrete/categorical variables. Classification with PLS is termed PLS-DA, where the DA stands for discriminant analysis. The PLS-DA algorithm has many favorable properties for dealing with multivariate data; one of the most important of which is how variable collinearity is dealt with, and the model's ability to rank variables' predictive capacities within a multivariate context. PLS-DA is performed in order to sharpen the separation between groups of observations, by hopefully rotating PCA (Principal Components
Analysis) components such that a maximum separation among classes is obtained, and to understand which variables carry the class separating information. Results from PLS-DA analysis are presented in the Fig. 3A. The accuracy of the model, the error rate or misclassification error is also provided. The loadings, scores and confusion matrix are provided in the supplementary report. PLS-DA model was satisfactory in classifying samples, a good separation from samples with and without fungicide was also found. The total variability captured was $62.02 \%$, being $49.41 \%$ and $12.61 \%$ for latent variable (LV) 1 and 2 respectively. Cultivar URS-FAPA-SLAVA.1 
separated alone. Besides, URS-BRAVA, UPFPS-FARROUPILHA, IPR-AFRODITE and URS-CORONA (without fungicide) clustered with those where fungicide application was performed. An error rate of $11.90 \%$ was found for our model. The circle of correlations (Fig. 3B) clearly indicates that cultivars without fungicide application were mostly affected by the lodging index and those with fungicide application by yield, de-hulling index and hectoliter weight. The loadings indicated that the first latent variable (LV1) was negatively influenced by all variables except the lodging index. LV2 was positively affected by lodging index and the grain yield. PLS-DA was the best technique in classifying samples beside the lower variability captured than PCA.

Table 2. Results of OLS regression

\begin{tabular}{|c|c|c|}
\hline & \multicolumn{2}{|c|}{ Dependent variable } \\
\hline & $\begin{array}{l}\text { Cult } \\
\text { (1) }\end{array}$ & $\begin{array}{l}\text { HW + DHI + Li } \\
\text { (2) }\end{array}$ \\
\hline $\mathrm{DHI}$ & $\begin{array}{l}0.06 \\
(0.05)\end{array}$ & \\
\hline HW & $\begin{array}{l}0.05 \\
(0.09)\end{array}$ & \\
\hline Li & $\begin{array}{l}0.01 \\
(0.01)\end{array}$ & \\
\hline PS & $\begin{array}{l}-0.02 \\
(0.03)\end{array}$ & $\begin{array}{l}1.56^{\star \star \star} \\
(0.12)\end{array}$ \\
\hline Sy & $\begin{array}{l}0.01 \\
(0.04)\end{array}$ & $\begin{array}{l}-0.42^{* \pi} \\
(0.20)\end{array}$ \\
\hline $\mathrm{Wg}$ & $\begin{array}{l}-0.06 \\
(0.06)\end{array}$ & $\begin{array}{l}-1.69^{* \pi \times} \\
(0.28)\end{array}$ \\
\hline Yield & $\begin{array}{l}-0.0004 \\
(0.0003)\end{array}$ & $\begin{array}{l}-0.004^{\approx \times x} \\
(0.002)\end{array}$ \\
\hline Application & $\begin{array}{l}0.09 \\
(0.61)\end{array}$ & $\begin{array}{l}4.93 \\
(3.17)\end{array}$ \\
\hline Cult & & $\begin{array}{l}0.38 \\
(0.24)\end{array}$ \\
\hline Constant & $\begin{array}{l}8.90^{* \pi} \\
(4.31)\end{array}$ & $\begin{array}{l}97.71^{* \pi \times} \\
(20.38)\end{array}$ \\
\hline Observations & 504 & 504 \\
\hline Akaike Inf. Crit. & $3,256.78$ & $4,935.05$ \\
\hline
\end{tabular}

\section{CONCLUSIONS}

Fungicide application affects the plant stature and lodging index in oat cultivars. The lodging index is negatively related to plant stature, and consequently influences the grain yield, the hectoliter weight and the sieve yield. Quality parameters of oats (hectoliter, de-hulling and lodging indices) are negatively affected by plant stature and positively by fungicide application.
Multivariate techniques (PCA, PLS-DA, OLS-R) classified samples according to fungicide application and were capable in finding the important variables that affect yield attributes and quality parameters and can be applied in a broad range of agricultural systems for predicting important aspects that affect plant growth and development.

\section{SUPPLEMENTARY DATA}

Detailed statistical analysis not shown in the manuscript can be found as supplementary data (https://drive.google.com/a/sciencedomain.org/fil e/d/0B6vYQhAC1gzHTVNhTUlwSTVSeDQ/view ?usp=sharing).

\section{ACKNOWLEDGEMENTS}

The financial support of CAPES-BRAZIL and CNPq-BRAZIL is to be acknowledged. The first author thanks CNPq for supporting the postdoctoral fellowship under the PNPD program and FAPESC-PAP-SC for article processing charges. The $2^{\text {nd }}$ and $4^{\text {th }}$ thanks CNPq for Research Productivity Fellowships.

\section{COMPETING INTERESTS}

Authors have declared that no competing interests exist.

\section{REFERENCES}

1. Sánchez-Martín J, Rubiales D, Flores F, Emeran A, Shtaya M, Sillero J, et al. Adaptation of oat (Avena sativa) cultivars to autumn sowings in Mediterranean environments. Field Crops Research. 2014;156:111-122.

2. Soltani N, Shropshire C, Sikkema P. Weed control and sensitivity of oats (Avena sativa) with various doses of saflufenacil. Crop Protection. 2012;31:4549.

3. Bilal $M$, Ayub $M$, Tariq $M$, Tahir $M$, Nadeem M. Dry matter yield and forage quality traits of oat ( Avena sativa L.) under integrative use of microbial and synthetic source of nitrogen. Journal of the Saudi Society of Agricultural Sciences. 2017; 16(3):236-241.

4. Nava I, Pacheco M, Federizzi L. URS Altiva - a new oat cultivar with high agronomic performance. Crop Breeding and Applied Biotechnology. 2016;16(3): 254-260. 
5. Zhou J, Zhang J, Li F, Liu J. Triazole fungicide tebuconazole disrupts human placental trophoblast cell functions. Journal of Hazardous Materials. 2016;308:294302.

6. Song Z, Nes W. Sterol biosynthesis inhibitors: Potential for transition state analogs and mechanism-based inactivators targeted at sterol methyltransferase. Lipids. 2007;42(1):1533.

7. Yang D, Wang N, Yan X, Shi J, Zhang M, Wang Z, et al. Microencapsulation of seedcoating tebuconazole and its effects on physiology and biochemistry of maize seedlings. Colloids and Surfaces B: Biointerfaces. 2014;114:241-246.

8. Marín $P$, de Ory A, Cruz A, Magan N, González-Jaén $M$. Potential effects of environmental conditions on the efficiency of the antifungal tebuconazole controlling Fusarium verticillioides and Fusarium proliferatum growth rate and Fumonisin biosynthesis. International Journal of Food Microbiology. 2013;165(3):251-258.

9. Patyal S, Sharma I, Chandel R, Dubey J. Dissipation kinetics of trifloxystrobin and tebuconazole on apple (Malus domestica) and soil - A multi location study from north western Himalayan region. Chemosphere. 2013;92(8):949-954.

10. Reuveni M. Efficacy of trifloxystrobin (Flint), a new strobilurin fungicide, in controlling powdery mildews on apple, mango and nectarine and rust on prune trees. Crop Protection. 2000;19(5):335341.

11. Diamantopoulou $P$, Philippoussis $A$, Kastanias M, Flouri F, ChrysayiTokousbalides M. Effect of famoxadone, tebuconazole and trifloxystrobin on Agaricus bisporus productivity and quality. Scientia Horticulturae. 2006;109(2):190195.

12. Veloukas T, Bardas G, Karaoglanidis G, Tzavella-Klonari K. Management of tomato leaf mould caused by Cladosporium fulvum with trifloxystrobin. Crop Protection. 2007; 26(6):845-851.

13. Bubici G, Amenduni M, Colella C, D'Amico M, Cirulli M. Efficacy of acibenzolar-Smethyl and two strobilurins, azoxystrobin and trifloxystrobin, for the control of corky root of tomato and verticillium wilt of eggplant. Crop Protection. 2006;25(8):814820.
14. Pérez $L$, Hernández $A$, Hernández $L$, Pérez M. Effect of trifloxystrobin and azoxystrobin on the control of black Sigatoka (Mycosphaerella fijiensis Morelet) on banana and plantain. Crop Protection. 2002;21(1):17-23.

5. 15 Cao M, Li S, Wang Q, Wei P, Liu Y, Zhu G et al. Track of fate and primary metabolism of trifloxystrobin in rice paddy ecosystem. Science of The Total Environment. 2015;518-519:417-423.

15. Matysiak K, Kaczmarek S. Effect of chlorocholine chloride and triazoles Tebuconazole and flusilazole on winter oilseed rape (Brassica napus Var. Oleifera L.) in Response to the application term and sowing density. Journal of Plant Protection Research. 2013;53(1).

16. Spence $\mathrm{C}$, Bais $\mathrm{H}$. Role of plant growth regulators as chemical signals in plantmicrobe interactions: A double edged sword. Current Opinion in Plant Biology. 2015;27:52-58.

17. Rademacher W. Growth retardants: Effects on gibberellin biosynthesis and other metabolic pathways. Annual Review of Plant Physiology and Plant Molecular Biology. 2000;51(1):501-531.

18. Wang C, Wang F, Zhang Q, Liang W. Individual and combined effects of tebuconazole and carbendazim on soil microbial activity. European Journal of Soil Biology. 2016;72:6-13.

19. Comissão Brasileira de Pesquisa de Aveia. Brazilian Oat Research Commission. Technical indications for oat culture. Guarapuava: Brazilian Oat Research Commission: Agrarian Research Foundation. 2006;82.

20. Moes J, Stobbe E. Barley treated with ethephon: I. Yield components and net grain yield. Agronomy Journal. 1991; 83(1):86.

21. $\mathrm{R}$ Core Team. R: A language and environment for statistical computing. $R$ Foundation for Statistical Computing, Vienna, Austria.

Available:https://www.R-project.org/.2017

22. lannucci A, Codianni P, Cattivelli L. Evaluation of genotype diversity in oat germplasm and definition of ideotypes Adapted to the Mediterranean Environment; 2017.

23. Lodhi MY, Marghazani B, Hamayun K, Marri MJ. Comparative performance study of different oat varieties under agro- 
climatic conditions of sibi. The Journal of Animal \& Plant Sciences. 2009;19:34-36.

24. Mourtzinis S, Shawn P, Conley SP, Gaska JM. Agronomic management and fungicide effects on oat yield and quality in wisconsin. 2015;1-4.

25. Brunava L, Jansone Z, Alsinga I. Grain yield and its forming parameters variations of oat cultivars. Acta Biol. Univ. Daugavp. 2015;15(2):251-257.

26. Oliveira A, Carvalho F, Maia L, Silva J, Hawerroth $M$, Nornberg $R$, et al. FAEM Chiarasul: new white oat cultivar with high yield and grain-processing quality. Crop Breeding and Applied Biotechnology. 2012;12(4):289-292.

27. Follmann D, Cargnelutti Filho A, Lúcio A, de Souza V, Caraffa M, Wartha C. Genetic progress in oat associated with fungicide use in Rio Grande do Sul, Brazil. Genetics and Molecular Research. 2016;15(4).

28. Gutkoski LC, Simioni D, de Oliveira M, Meneghetti VL., Oliveira LC, Elias MC. Drying and storage conditions in white oat grains quality. PS1-10 - 6276, pp78-84. In: I. Lorini B, Bacaltchuk $\mathrm{H}$, Beckel D, Deckers E, Sundfeld J PS, J. D. Biagi, J.
C. Celaro, L. R. D'A. Faroni, L.de O. F. Bortolini, M. R. Sartori, M. C. Elias, R. N. C. Guedes, R. G. da Fonseca, V. M. Scussel (eds.), Proceedings of the 9th International Working Conference on Stored Product Protection, 15 to 18 October 2006, Campinas, São Paulo, Brazil. Brazilian Post-harvest Association ABRAPOS, Passo Fundo, RS, Brazil, 2006.

ISBN: 8560234004

29. Kolchinski E, Schuch L. Grain quality parameters and seeds quality in oat in relation to nitrogen fertilization availability. Ciência Rural. 2003;33(3):587-589.

30. Emvula S. Assessment of hectolitre mass $(\mathrm{HIm})$ equipment and $\mathrm{HIm}$ measurements of oats. Master of Science in Food Science. Stellenbosch University; 2012.

31. Hancock NI, Smith EL. University of tennessee agricultural experiment station, "Lodging in Small Grains". Bulletins; 1963.

32. Biel W, Jacyno E, Kawęcka M. Chemical composition of hulled, dehulled and naked oat grains. South African Journal of Animal Science. 2014; 44(2):189.

(c) 2017 Uarrota et al.; This is an Open Access article distributed under the terms of the Creative Commons Attribution License (http://creativecommons.org/licenses/by/4.0), which permits unrestricted use, distribution, and reproduction in any medium, provided the original work is properly cited.

Peer-review history:

The peer review history for this paper can be accessed here: http://sciencedomain.org/review-history/20872 